\title{
The stability and growth pact, fiscal policy institutions and stabilization in Europe
}

\author{
Carlos Fonseca Marinheiro
}

Published online: 5 April 2008

C) Springer-Verlag 2008

\begin{abstract}
Ever since its inception, the EMU has been subject to controversy. The fiscal policy rules embedded in the Maastricht Treaty, and clarified in the Stability and Growth Pact (SGP), are probably the most contentious. The SGP has constantly been accused of being too rigid and of forcing procyclicality in fiscal policy. However, in an influential paper Galí and Perotti (2003) concluded that discretionary fiscal policy has actually become more countercyclical in EMU countries since the Maastricht Treaty. This paper argues that this conclusion stands up to several robustness tests using ex-post data, including the use of institutional variables, but not to the use of real-time data. Using ex-post data, there is some evidence pointing to a more countercyclical use of discretionary fiscal policy (or at least to less use of procyclical discretionary fiscal policy). However, the use of real-time data for the period 1999-2006 reveals that discretionary fiscal policy has been designed to be procyclical. Hence, the actual acyclical behaviour of discretionary fiscal policy in the period after 1999 seems to be simply the result of errors in forecasting the output gap, and not the result of a change in the intentions of policy-makers. As a result, there is no evidence to support the view that Maastricht rules have forced euro-area policy-makers to change their behaviour and design countercyclical discretionary fiscal policies.
\end{abstract}

Keywords Fiscal policy - Stabilization - Stability and growth pact Institutional arrangements $\cdot$ Real-time data

C. F. Marinheiro $(\bowtie)$

Grupo de Estudos Monetários e Financeiros (GEMF), Faculty of Economics, University of Coimbra, Av. Dias da Silva,

165, 3004-512 Coimbra, Portugal

e-mail: marinheiro@fe.uc.pt

URL: http://www4.fe.uc.pt/carlosm 


\section{JEL Classification E62 $\cdot \mathrm{H} 62$}

\section{Introduction}

The completion of the EMU in Europe, with the introduction of the single currencythe euro - in 1999, has greatly affected the conduct of economic policy in the twelve participating member states. The only traditional short-term macroeconomic instrument that remains in the control of national authorities is fiscal policy. Consequently, fiscal policy has gained new responsibilities under the EMU, but at the same time the Stability and Growth Pact (SGP) constrains its operation. Fiscal policy must now provide output smoothing, especially the smoothing of asymmetric shocks, and contribute to attaining price stability and external balance (in the case of a twin deficit). These new objectives are particularly important for the case of small countries out of synchrony with the rest of the monetary union and require a flexible fiscal policy. This paper therefore aims to evaluate the actual cyclical properties of discretionary fiscal policy.

It has been argued that the fiscal rules imposed by the SGP would lead to the need to override the workings of the automatic fiscal stabilisers, resulting in a procyclical discretionary fiscal policy. However, in an influential paper Galí and Perotti (2003) argued that the opposite was true: discretionary fiscal policy in EMU countries had in fact become more countercyclical after the signing of the Maastricht Treaty in 1992, following the trend of other industrialized countries.

This paper contributes to the literature assessing the robustness of such a finding in a number of different ways. First, it will use a different dataset for all the $15 \mathrm{EU}$ countries except Luxembourg. Galí and Perotti (2003) used OECD data, while here the main source of data is the AMECO database from the European Commission (autumn 2006 version). Second, it will also test for a different sub-period division. The two authors distinguished the period before and the one after 1992. This paper breaks down the post-1992 period into greater detail. Third, the impact of an extension of the estimation period to 2006 is tested, too, i.e. three more years of the EMU are included. Fourth, this paper tests the validity of the authors' conclusions concerning the inclusion of controls for the effects of political-institutional variables on the cyclically adjusted primary deficit. Fifth, and last, this paper tests the validity of the previous conclusions to the use of real-time data for the period 1999-2006. Galí and Perotti's conclusions are found to be robust for the first four tests, but not for the use of real-time data.

The structure of the paper is as follows. Section II presents the methodology and data used in the empirical application. Section III presents the empirical results. The conclusions are discussed in Section IV.

\section{Methodology and data}

The study is based on a panel data estimation for all 15 European countries, except Luxembourg. The source of data is the November 2006 version of the AMECO 
database of the European Commission, complemented with OECD Economic Outlook data for some years. ${ }^{1}$ Since the purpose of the paper is to test for the robustness of the specification of Galí and Perotti (2003), the point of departure will be their specification:

$$
d_{t}^{*}=\varphi_{0}+\varphi_{x} E_{t-1} x_{t}+\varphi_{b} b_{t-1}+\varphi_{d} d_{t-1}^{*}+\mu_{t}
$$

where $d_{t}^{*}$ is the cyclically adjusted primary deficit, $\mathrm{E}_{t-1} . x_{t}$ is the expected output gap, and $b_{t-1}$ is the debt outstanding at the time of the budget decision (all variables are expressed as a share of potential GDP). ${ }^{2}$ The inclusion of the lagged debt ratio allows control for sustainability considerations in the conduct of fiscal policy.

If fiscal policy were being used as a purely countercyclical instrument to dampen the amplitude of the business cycle, that is, if the automatic stabilisers were allowed to work freely over the cycle, we should observe an increase in the budget deficit during recessions and an improvement during upturns. This implies a negative reaction of the budget deficit to the output gap. Since interest is focused on the behaviour of discretionary fiscal policy, cyclically adjusted data is used. If automatic stabilisation alone occurs, the cyclically adjusted deficit does not respond to the state of the economy. However, in practice, policy-makers can use discretionary fiscal policy to reinforce the automatic stabilisers (in a countercyclical way) or to counteract their action (in a pro-cyclical way). The use of the cyclically adjusted primary deficit as a proxy for discretionary actions is already standard in the literature, although in practice there are several difficulties in disentangling automatic fiscal policy variations from discretionary actions. ${ }^{3}$

The expected output gap was proxied by Galí and Perotti (2003) by means of instrumental variable estimation. More precisely, for the EU countries, the output gap variable is instrumented by the lagged output and by the lagged US output. Hence, following Gali and Perotti (2003), the results of this paper are obtained allowing for different intercepts for each country using an instrumental variable (IV) fixed effects (LSDV) estimator. When using fixed effects, the inference is conditional on the particular set of countries and for the specific time periods

\footnotetext{
${ }^{1}$ In order to reach a balanced panel, some missing AMECO values were carefully linked with observations from the OECD Economic Outlook database. Some cyclically adjusted fiscal data are only available for some countries several years after 1980 in the AMECO database, e.g. Greece (1988), Ireland (1995), Spain (1995) and Sweden (1993). Data on the unadjusted balances, and the (calculated) implied sensitivity to the cycle were taken from the OECD database. Using it together with the output gap from AMECO resulted in linked series. The OECD database is also the source of the US output gap estimate.

${ }^{2}$ Potential output is used as a deflator of all variables, instead of actual output, to reduce endogeneity problems and to minimize the influence of current GDP on the evolution of the fiscal ratios. See Bayoumi and Masson (1995) for a similar use. The output gap is defined as the difference between current and potential output as a fraction of potential output.

${ }^{3}$ The use of primary balance instead of the overall budget balance is motivated by the fact that interest payments are not under the control of the fiscal authorities, but simply reflect the evolution of the interest rate and the past accumulation of budget deficits. See also Brandner, Diebalek et al. (2006) for an application of an unobserved components model to estimate a core balance for Austria.
} 
observed, which is precisely the objective. ${ }^{4,5}$ A promising alternative to proxy for the expected output gap would be to use "real-time data", as in Forni and Momigliano (2004). However, such data is only available from 1993 onwards, invalidating its use in comparisons between the pre-euro and post-euro period. Section 3.4 makes use of this kind of data for the period after the introduction of the euro (1999-2006).

There are also other interesting specifications in the literature to test for the cyclical properties of fiscal policy (see Wyplosz (2002), Auerbach (2002), Lane (2003), and Pina (2004)). However, since the purpose is to test for the robustness of the conclusions of Galí and Perotti (2003), it makes sense to use their specification to get directly comparable results.

At any rate, since the seminal contribution of Roubini and Sachs (1989), an increasing number of papers have signalled the importance of the institutional design of national budget institutions to the size of budget deficits (see Brender and Drazen (2005), Volkerink and de Haan (2001), Mierau et al. (2006), Woo (2003), for example). Hence, the omission of such important variables might bias the previous results. As a result this paper incorporates some of these political-institutional variables into the reaction function proposed by Galí and Perotti (2003) to test for the robustness of the authors' conclusions. The data source of such variables is Mierau et al. (2006). ${ }^{6}$

\section{Empirical evidence on the effective cyclical properties of fiscal policy}

The importance of fiscal policy as a countercyclical stabilisation mechanism means that it makes sense to see whether fiscal policy has in fact been used in Europe with such considerations in mind. Some feared that the EMU rules might force an overriding of automatic stabilizers by a procyclical use of discretionary fiscal policy. ${ }^{7}$ Galí and Perotti (2003) concluded that the Maastricht rules signalled a shift of discretionary fiscal policy towards its use as a more countercyclical instrument. This section will empirically test the robustness of this conclusion.

\footnotetext{
${ }^{4}$ See Baltagi (2001).

${ }^{5}$ There is however a technical caveat regarding the use of fixed effects with a lagged endogenous variable resulting in inconsistent estimators. The alternative would be to use the estimator proposed by Arellano and Bond (1991). However, the small-sample properties of such an estimator are not well understood. Moreover, as much of the focus is on the difference between the estimates of the gap coefficient between two periods, I have, as Galí and Perotti (2003: note 6) did, opted to present the results with a standard instrumental variables fixed effects estimator. Notwithstanding, Table 6 in the appendix presents some results using the Arellano and Bond estimation method.

${ }^{6}$ This paper makes use of the more recent version of this database (received from the authors in January 2006 and last updated in February 2007), i.e. the version used in Mierau et al. (2007) in Public Choice.

${ }^{7}$ For a discussion on the usefulness and desirability of discretionary fiscal policy, see the excellent surveys by Andersen (2001) and Auerbach (2002).
} 


\subsection{The impact of the euro}

The empirical results of this paper are based on a (balanced) panel estimation of the determinants of the cyclically adjusted primary deficit, as set forth in equation (1), for the EU-15 countries, including all the euro-area countries (except Luxembourg). As mentioned before, the dependent variable is the cyclically adjusted primary deficit (as a percentage of potential GDP). Since this variable is, by definition, immune to cyclical developments and not influenced by past debt accumulation, its evolution over time is an indicator of discretionary fiscal policy. A positive coefficient for the output gap variable can be interpreted as a procyclical discretionary fiscal policy.

In order to replicate the results of Galí and Perotti (2003), we have only slightly modified their estimation. Equation (1) is estimated by Galí and Perotti (2003) allowing for a break to occur in 1992 in all the variables (output gap, lagged debt, and lagged deficit), plus a break in the country-fixed effects. However, their results do not indicate a break in the lagged debt and lagged deficit variables. Hence, in order to reduce the number of regressors, we have differed by only allowing a break to occur for the output gap variable. In common with Galí and Perotti (2003), we have used the instruments lagged output gap and lagged US output gap for the expected output gap.

The empirical results, along with a reproduction of Galí and Perotti's most relevant results, are presented in Table 1. The first column of the table just reproduces Galí and Perotti's (2003: 550) results for the EMU countries for the period 1980-2003, showing evidence for an increase in the degree of countercyclicality of discretionary fiscal policy after the signing of the Maastricht Treaty in 1992. According to their results, discretionary fiscal policy was procyclical before 1992 and became acyclical after Maastricht. Moreover, the authors concluded that the difference between the output gap coefficients for these two sub-periods is statistically significant.

The second column tries to replicate these results for the same period, but for the 12 economies (except Luxembourg), using a different dataset. ${ }^{8}$ The results are very similar to those of Galí and Perotti (2003) shown in column (1). Discretionary fiscal policy is found to be procyclical before 1992, and acyclical after 1992. The difference between the gap coefficients for the two sub-periods is also statistically significant.

Next, a different subdivision of time was tested. Although the Maastricht Treaty was signed in 1992, it provided for three stages until the adoption of a common currency, and the date for the start of stage III was not defined initially. The Treaty stated only that if, "by the end of 1997, the date for the beginning of the third stage has not been set, the third stage shall start on 1 January 1999". It was only in December 1995 that the European Council confirmed that stage three of the EMU would start on 1 January 1999. In order for a country to qualify to sign up to the euro, it was required to achieve a budget deficit below the reference value of $3 \%$ of

\footnotetext{
${ }^{8}$ Gali and Perotti (2003) used OECD data; here the main source of data is the AMECO database, from the European Commission.
} 


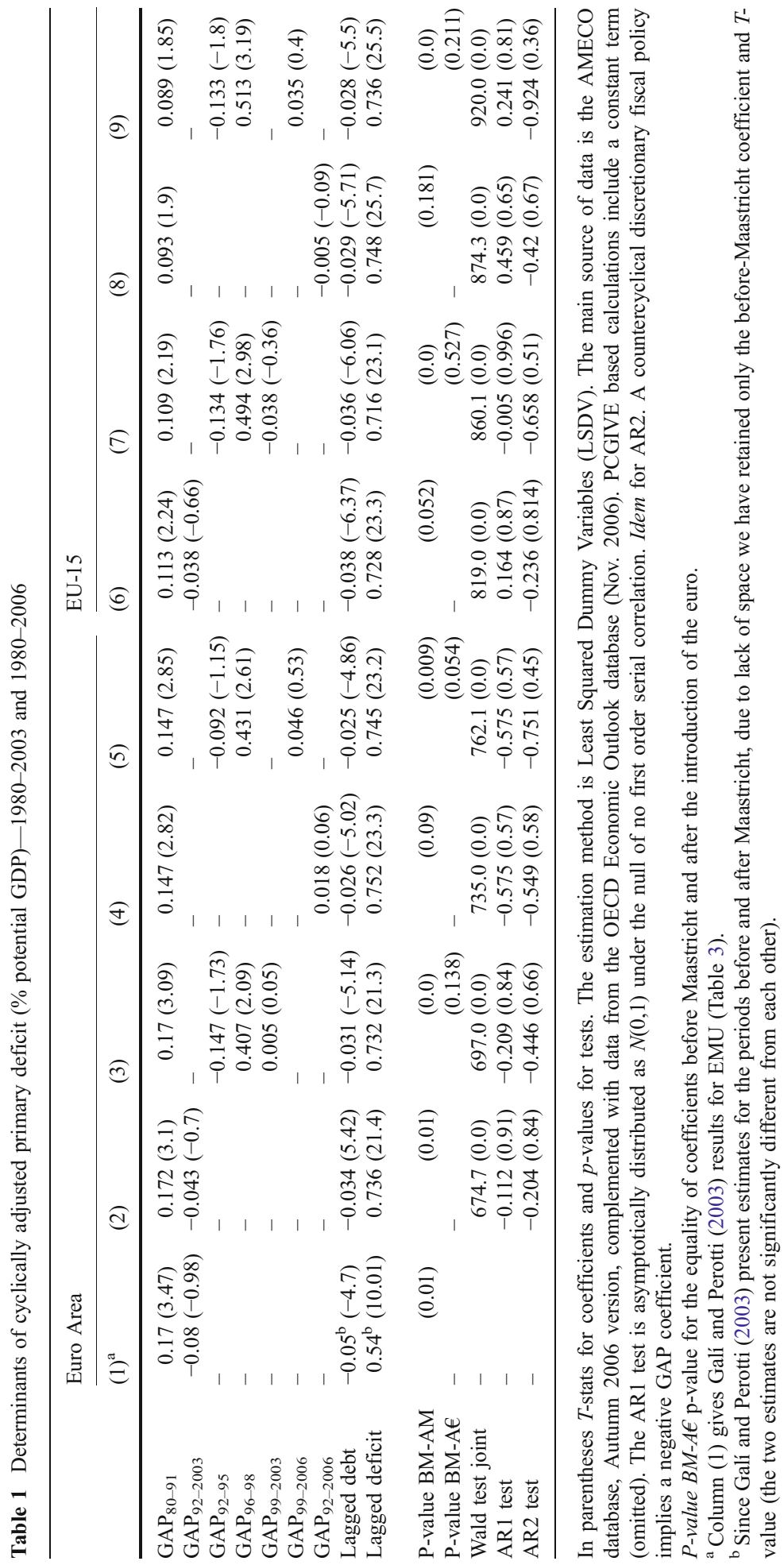


GDP before the start of stage three. Hence, it might make sense to subdivide the post-Maastricht period (1992-2003) into three different sub-periods: 1992-1995; 1996-1998; and, finally 1999-2003. The first sub-period started immediately after the signing of the Treaty, but before the decision on the start of EMU was taken. Hence, the consolidation efforts towards the $3 \%$ were relatively modest. ${ }^{9}$ The $1996-$ 1998 period is the run-up period to the single currency. The start of the third stage was already set at 1999, and member countries did in fact made intensive consolidation efforts in this period, since the time to qualify for membership of the monetary union was rapidly running out. Finally, the last sub-period, 1999-2003, is the period after the introduction of the euro. The 3\% rule is still binding, under the Stability and Growth Pact (SGP) provisions, but there is no provision for a country that fails to keep its deficit under the $3 \%$ ceiling to be expelled from the euro area. Hence, the actual start of the single currency might have induced different fiscal policy behaviour from the qualifying stage.

Accordingly, column (3) shows the empirical results when the period after Maastricht is divided into the three sub-periods defined above. The result for the preMaastricht period is unaffected by the sub-division: discretionary fiscal policy is found to be procyclical in this sub-period. Yet, there is considerable variation in the post-1992 sub-period. The period immediately after the signing of the Treaty (19921995 ) is characterized (at the 10\% significance level) by countercyclical discretionary fiscal policy. However, the run-up to qualification for EMU (1996-1998) is characterized by a strong procyclical discretionary fiscal policy stance. The posteuro period (1999-2003) is characterized by an acyclical discretionary fiscal policy.

Next, the period under analysis was extended to 2006 (in the previous results it ended in 2003, as in Galí and Perotti (2003)). The earlier conclusions are robust to the addition of three more years to the euro sub-period. The results are in columns (4) and (5). Column (4) presents the results for Galí and Perotti's subdivision of time (before and after Maastricht), while column (5) presents the results when further disaggregating the post-Maastricht period.

A different sub-division of time was also tested, considering the sub-period before and after the introduction of the euro. The results (not reported) were not substantially different from the reported ones: before the introduction of the euro, discretionary fiscal policy is found to be procyclical, and becomes acyclical with the introduction of the euro.

Columns (6)-(9) extend the number of countries considered to encompass all EU15 member countries, with the exception of Luxembourg. The results are very similar to those obtained for the euro area. Discretionary fiscal policy exhibits procyclical behaviour in the pre-Maastricht period and is mostly acyclical after 1992. Further subdivision of the post-Maastricht period yields the same conclusions as before. Immediately after 1992, discretionary fiscal policy shows countercyclical behaviour, which is reversed in the run-up to the single currency (1996-1998). After the introduction of the euro, discretionary fiscal policy does not react immediately to business cycle fluctuations.

\footnotetext{
${ }^{9}$ Stage II of EMU started only in 1994, and it was clear to participants that phase III would only start on the date limit imposed by article 121 of the Treaty (1999).
} 
With regard to the other controls included in the regression, the lagged debt and the lagged deficit are both statistically significant. The estimated debt coefficient is negative, ranging from -0.025 to -0.036 , meaning that the average country reduced the structural primary deficit by approximately 0.03 of potential GDP for each additional point of debt in the previous year. This value, although small, means that sustainability considerations entered into discretionary fiscal policy decisions.

\subsection{The impact of the euro and institutional variables}

This section looks at whether the previous conclusions regarding the cyclical behaviour of discretionary fiscal policy are robust to controlling for the impact of institutional aspects. Bearing this in mind, equation (1) is augmented with the inclusion of political-institutional variables. In the practical estimation, proxies for political fragmentation in government or Parliament, and data on the occurrence of elections or the formation of a new government were used.

Following Volkerink and de Haan (2001), the following variables were considered. As proxies of size fragmentation: the effective number of parties in government (ENoP_G); the effective number of parties in parliament (ENoP_P), capturing the government's position vis-à-vis parliament; the number of spending ministers (NSM), i.e. simply the total number of ministers in government minus the ministers of finance and/or the budget and the prime minister; and, seats in excess of coalition seats in parliament (surplus seats) were used. Measures of political fragmentation in government/parliament were political fragmentation in government (Frag_G) and political fragmentation in Parliament (Frag_P). The latter variable might be relevant because the more politically divided parliament is, the less the government may have to fear from the opposition. Finally, dummies for elections (Elect) and for the formation of a new government (NewGov) were also considered.

As expected, there is a high degree of correlation between the variables related to parliament and government, since the latter emanates from the former (see Table 2). There is also a high degree of correlation between the occurrence of elections and the formation of a new government. As a result, in order to avoid multicollinearity problems, it is not advisable to include government and parliament variables in the same regression. Since the purpose is to determine the orientation of discretionary

Table 2 Correlation among political variables in the euro area-1980-2003

\begin{tabular}{lccrrrrrr}
\hline & ENoP_G & ENoP_P & NSM & Frag_P & Frag_G & Surplus S. & NewGov & Elect \\
\hline ENoP_G & \multirow{2}{*}{1.00} & 0.86 & -0.13 & 0.42 & 0.63 & 0.30 & 0.08 & 0.01 \\
ENoP_P & & 1.00 & -0.22 & 0.33 & 0.49 & 0.07 & 0.07 & 0.03 \\
NSM & & & 1.00 & 0.14 & -0.22 & 0.04 & 0.11 & -0.05 \\
Frag_P & & & 1.00 & 0.32 & 0.02 & 0.04 & -0.02 \\
Frag_G & & & & 1.00 & 0.18 & -0.01 & 0.01 \\
Surplus Seats & & & & 1.00 & 0.05 & 0.00 & 0.70 \\
NewGov & & & & & & & & \\
Elect & & & & & & & & \\
\hline
\end{tabular}

Source of data: Mierau et al. (2006).

Springer 
policy, it was opted just to retain the indication of the amount of fragmentation in government (number of parties in government, number of spending ministers), and the number of excess seats in parliament. In addition, the election dummy is also included.

Political fragmentation variables were not retained because they proved to be not statistically significant. In line with the results in Volkerink and de Haan (2001), government ideology was found to have no impact on the cyclically adjusted primary deficit. Hence there is no support for the view that argues that, as left-wing parties would like to spend more, they are also likely to have higher structural primary deficits. A possible explanation is given by Volkerink and de Haan (2001). According to them, left-wing governments do not have higher deficits than rightwing governments, because although they spend more, they also tax more, leaving the balance unaltered.

Table 3 presents the results for the determinants of cyclically adjusted primary deficit when controlling for the effects of political-institutional variables for the period 1980-2003. ${ }^{10}$ For convenience, column (1) repeats the same regression shown previously in column (2) of Table 1 . With regard to the institutional variables, it can be seen that elections have a significant positive impact on the cyclically adjusted primary deficit (CAPD), meaning that elections induce a discretionary fiscal expansion. The effective number of parties in government (ENoP_G) has a negative but not statistically significant impact on the CAPD. The excess seats the government has in parliament also has a non-statistically significant negative impact on the CAPD. In contrast, the number of spending ministers (NSM) has a strongly positive and statistically significant impact on the CAPD.

An important finding is that the previous results for the impact of introducing the euro are robust even after controlling for those political variables, except in the last specification. In general, discretionary fiscal policy is found to be procyclical in the period before Maastricht. After Maastricht, the same comments apply as before: the run-up period to the single currency was characterized by procyclical behaviour, but the period after 1999 is characterized by the non-reaction of discretionary fiscal policy to the cyclical conditions prevailing in the economy. ${ }^{11}$

It was also investigated whether some institutional variables have a direct impact on the reaction of discretionary policy to the output gap. To do this, interaction terms were included, one at a time, between the political-institutional variables and the output gap. Column (4) presents the results, including the interacted effective number of parties in government. Its coefficient has a negative sign and is statistically significant at the $10 \%$ level. It means that coalition governments (especially those involving more than two parties) show a tendency to design more countercyclical fiscal policies. This might be a side-effect of the negotiations of coalition agreements, which constrain the liberty of a given party to manipulate the deficit for its own purposes. Next, the interacted number of spending ministers was included. The coefficient is positive, small and statistically significant at the $10 \%$

\footnotetext{
${ }^{10}$ The political-institutional variables of Mierau et al. (2006) are only available until 2003.

11 The difference between the estimates for the gap before and after Maastricht is statistically significant in all regressions.
} 
Table 3 Determinants of cyclically adjusted primary deficit (\%Potential GDP)—1980-2003

\begin{tabular}{|c|c|c|c|c|c|}
\hline & \multicolumn{5}{|l|}{ Euro Area } \\
\hline & (1) & (2) & (3) & (4) & (5) \\
\hline $\mathrm{GAP}_{80-91}$ & $0.172(3.1)$ & $0.174(3.22)$ & $0.172(3.22)$ & $0.326(3.27)$ & $-0.150(0.75)$ \\
\hline $\mathrm{GAP}_{92-2003}$ & $-0.043(-0.7)$ & $-0.05(-0.83)$ & - & $0.122(1.09)$ & $-0.354(-1.85)$ \\
\hline $\mathrm{GAP}_{92-95}$ & - & - & $-0.165(-2.03)$ & - & - \\
\hline $\mathrm{GAP}_{96-98}$ & - & - & 0.372 (1.99) & - & - \\
\hline GAP $_{99-2003}$ & - & - & $0.025(0.24)$ & - & - \\
\hline Elections & - & $0.741(3.93)$ & $0.751(4.02)$ & $0.724(3.85)$ & $0.76(4.03)$ \\
\hline ENoP_G & - & $-0.094(-0.47)$ & $-0.085(-0.43)$ & $-0.051(-0.26)$ & $-0.098(-0.49)$ \\
\hline Surplus seats & - & $-1.467(-1.07)$ & $-1.571(-1.16)$ & $-1.414(-1.04)$ & $-0.978(-0.7)$ \\
\hline NSM & - & $0.15(3.17)$ & $0.147(3.14)$ & $0.161(3.38)$ & $0.149(3.15)$ \\
\hline GAP*NSM & - & - & - & - & $0.02(1.67)$ \\
\hline GAP*ENoP_G & - & - & - & $-0.083(-1.81)$ & \\
\hline Lagged debt & $-0.034(5.42)$ & $-0.031(-5.16)$ & $-0.029(-4.89)$ & $-0.029(-4.92)$ & $-0.033(-5.41)$ \\
\hline Lagged deficit & $0.736(21.4)$ & $0.717(21.2)$ & $0.715(21.2)$ & 0.709 (20.9) & $0.711(21)$ \\
\hline P-value BM-AM & $(0.01)$ & $(0.01)$ & $(0.0)$ & $(0.01)$ & $(0.015)$ \\
\hline P-value BM-A€ & - & - & $(0.083)$ & - & - \\
\hline Wald test joint & $674.7(0.0)$ & $767.1(0.0)$ & $794.6(0.0)$ & $777.9(0.0)$ & $775.8(0.0)$ \\
\hline AR1 test & $-0.112(0.91)$ & $0.34(0.73)$ & $0.163(0.87)$ & $0.307(0.76)$ & $0.38(0.7)$ \\
\hline AR2 test & $-0.204(0.84)$ & $-0.02(0.98)$ & $-0.274(0.78)$ & $0.025(0.98)$ & $0.259(0.8)$ \\
\hline
\end{tabular}

In parentheses $t$-stats for coefficients and $p$-values for tests. The estimation method is Least Squared Dummy Variables (LSDV).

$P$-value $B M-A M$ p-value for the equality of coefficients before and after Maastricht, $P$-value $B M$ - $A € \mathrm{p}$ value for the equality of coefficients before Maastricht and after the introduction of the euro. See text for details.

level. ${ }^{12}$ The result indicates that the larger the government, the more likely it is to pursue a procyclical discretionary fiscal policy.

\subsection{High and low deficit countries}

The previous results were obtained using a panel regression, which imposes the same fiscal reaction across all countries considered. This section examines whether there are major variations across groups of countries, and at the country level in the euro area.

First, the euro-area countries were divided into high-deficit and low-deficit countries. Countries were divided into two subgroups according to their cyclically adjusted average primary deficit level in the period before the run-up to the single currency. Hence, countries whose average deficit in the 1980-1995 period was larger than the unweighted euro-area average were classified as "high-deficit countries". Table 4 presents a panel estimate distinguishing the two groups of countries and the preferred temporal subdivision. There is some evidence that the high-deficit countries make a more procyclical use of discretionary fiscal policy than low-deficit

\footnotetext{
12 The inclusion of an interaction term renders the output gap before Maastricht non-statistically significant. At the $10 \%$ level, discretionary fiscal policy is found to be countercyclical after Maastricht.
} 
Table 4 Determinants of cyclically adjusted primary deficit (\%Potential GDP)—panel for the euro-area countries: high and low deficit countries-1980-2006

\begin{tabular}{|c|c|c|c|}
\hline & Deficit level & $1980-2006$ & $1980-2003$ \\
\hline \multirow[t]{2}{*}{$\mathrm{GAP}_{80-91}$} & High & $0.167(4.2)$ & $0.152(3.09)$ \\
\hline & Low & $0.117(1.18)$ & $0.152(1.45)$ \\
\hline \multirow[t]{2}{*}{$\mathrm{GAP}_{92-95}$} & High & $0.174(1.14)$ & $0.165(0.95)$ \\
\hline & Low & $-0.28(-4.06)$ & $-0.297(-3.28)$ \\
\hline \multirow[t]{2}{*}{$\mathrm{GAP}_{96-98}$} & High & $0.566(2.96)$ & $0.463(2.23)$ \\
\hline & Low & $0.357(2.85)$ & $0.407(3.11)$ \\
\hline \multirow[t]{2}{*}{ GAP $_{99-2003 / 6}$} & High & $0.077(2.89)$ & $0.087(1.28)$ \\
\hline & Low & $-0.037(-0.29)$ & $-0.106(-1.15)$ \\
\hline Elections & & - & $0.684(3.96)$ \\
\hline ENoP_G & & - & $-0.093(-0.58)$ \\
\hline Surplus seats & & - & $-0.713(-0.78)$ \\
\hline NSM & & - & $0.142(2.1)$ \\
\hline Lagged debt & & $-0.025(-3.47)$ & $-0.027(-5.26)$ \\
\hline Lagged deficit & & $0.723(12.9)$ & $0.687(11.9)$ \\
\hline \multirow[t]{2}{*}{ P-value equal coeff. } & High & $(0.0)$ & $(0.02)$ \\
\hline & Low & $(0.0)$ & $(0.0)$ \\
\hline \multirow[t]{2}{*}{$\mathrm{P}$-value equal coeff. BM/A€ } & High & $(0.0)$ & $(0.097)$ \\
\hline & Low & $(0.15)$ & $(0.0)$ \\
\hline Wald test joint & & $-(0.0)$ & $127.6(0.0)$ \\
\hline AR1 test & & $-0.75(0.45)$ & $-0.808(0.42)$ \\
\hline AR2 test & & $-1.217(0.22)$ & $-1.08(0.28)$ \\
\hline
\end{tabular}

In parentheses $T$-stats for coefficients and $p$-values for tests. The estimation method is Least Squared Dummy Variables (LSDV). See text for details.

countries do. For high-deficit countries a procyclical discretionary fiscal policy is found for the period before Maastricht, in the run-up period, and after $1999 .{ }^{13}$ For low-deficit countries, only in the run-up period to the euro (1996-1998) is this found: both before Maastricht and after the introduction of the euro, discretionary fiscal policy is broadly acyclical. ${ }^{14}$ The inclusion of the institutional variables (and the consequent loss of three years of data) does not affect these conclusions.

Second, the same fiscal reaction equation is estimated at the country level in the eleven euro-area countries considered. The results are shown in Table 7 in the appendix. There is a limited amount of variation in the cyclical properties of discretionary fiscal policy across countries. A majority of countries had procyclical discretionary fiscal policies before Maastricht (and all of them had a positive coefficient on the output gap). After the introduction of the euro, in the 1999-2006 period, all but two countries had acyclical discretionary fiscal policies. The exceptions are Greece and Spain, which adopted a procyclical stance. ${ }^{15}$ Moreover,

\footnotetext{
${ }^{13}$ When controlling for institutional variables, discretionary fiscal policy after the introduction of the euro is found to be acyclical in high-deficit countries, since the positive coefficient on the gap is not statistically significant.

${ }^{14}$ Moreover, there is a change in sign in the non-statistically significant coefficient on the output gap. While it is positive in the period before Maastricht, it is negative in the period after the introduction of the euro.
}

15 The regression for Portugal presents a low fit to the data. 
in the nine countries with an acyclical fiscal policy, five have a negative gap coefficient, and the other four a positive one. A statistically significant negative coefficient signals a countercyclical discretionary fiscal policy. However, due to the general non-statistical significance of the output gap coefficient in the period after 1999, the hypothesis of an equal coefficient for the period before Maastricht and after the euro is formally rejected by the data only for Italy.

\subsection{Use of real-time data}

In the preceding sections, ex-post data on the output gap was used to assess the actual degree of countercyclicality of discretionary fiscal policy. There is, however, a caveat to the use of ex-post data: when designing future fiscal policy decisions policy-makers do not have such data available, and have to resort to (ex-ante) realtime output gap estimates. Such estimates may, and usually do, differ from actual (ex-post) gap estimates, which use more information than that available at the time of the decision (see Orphanides and van Norden (2002)).

A practical limitation on the use of real-time data is that international organizations started to produce comparable estimates of output gaps only relatively recently, in the late 1990s. This makes it impossible to estimate fiscal rules comparing the period before Maastricht with the period after Maastricht using realtime data. Nevertheless, in a leading paper, Forni and Momigliano (2004) estimated a fiscal rule using real-time data on the output gap as calculated by the OECD for the period 1993-2003. Diverging from Galí and Perotti (2003), the authors distinguished the fiscal policy reaction in favourable cyclical conditions from the fiscal reaction during adverse cyclical conditions. They found a countercyclical reaction of discretionary fiscal policy to adverse economic conditions, and again a negative (but not statistically significant) reaction of the deficit to the output gap during favourable economic conditions. These results contrast with their own estimates using ex-post data when the estimated reaction of fiscal policy to adverse cyclical conditions was weaker and not statistically significant.

In order to estimate a fiscal reaction with real-time data, this paper collected the output gap estimates for year $t$ made by the European Commission in the spring and autumn of the previous year $(t-1)$. The data only starts in 1999. This real-time estimate on the output gap was then used together with the rest of the previously used (ex-post) data. ${ }^{16}$ The LSDV results are shown in Table 5. As the majority of national budgets in Europe are submitted to the respective national Parliaments in September/October, and the autumn forecast is only made public in November, in my opinion the most relevant forecast is the Spring forecast (made in year $t-1$ for year $t$ ), since this is the only (Commission) forecast available at the time the budget decisions are made by the national governments. Due to the short time scale of this real-time data, it is not possible to distinguish positive from negative output gaps, or historically high-deficit countries from low-deficit countries.

\footnotetext{
${ }^{16}$ For instance, the measure of the output gap for 2001 used in the regression was the forecast of the output gap made by the Commission services in the Spring (or Autumn) of 2000. 
Table 5 Determinants of a cyclically adjusted primary deficit (\%Potential GDP) - panel for the euro-area countries using real-time data-1999-2006

\begin{tabular}{lcc}
\hline & \multicolumn{2}{l}{ Forecast made in: } \\
\cline { 2 - 3 } & Spring $_{t-1}$ & Autumn $_{t-1}$ \\
\hline GAP $_{\mathrm{t}}$ & $0.336(3.96)$ & $0.223(2.06)$ \\
Lagged debt & $-0.018(-1.15)$ & $-0.026(-1.23)$ \\
Lagged deficit & $0.496(7.79)$ & $0.545(7.48)$ \\
Wald test joint & $121.1(0.0)$ & $96.2(0.0)$ \\
AR1 test & $-1.21(0.23)$ & $-1.09(0.28)$ \\
AR2 test & $-2.05(0.04)$ & $-2.06(0.04)$ \\
\hline
\end{tabular}

In parentheses $t$-stats for coefficients and $p$-values for tests. The estimation method is Least Squared Dummy Variables (LSDV) using robust standard errors. See text for details.

The results obtained here point to a positive, and statistically significant, coefficient on the (ex-ante) output gap variable. This signals that discretionary fiscal policy has been planned since 1999 to be procyclical. This finding contrasts with the previous results based on ex-post data, and also with Forni and Momigliano (2004). ${ }^{17}$ As seen before, using ex-post data, the euro period (1999-2006) was characterized by an acyclical discretionary fiscal policy (due to a small, positive but non-statistically significant coefficient on the gap variable). In contrast, using this ex-ante data, the coefficient on the output gap is much larger $(0.336$ using the spring forecast) and statistically significant. This indicates that the discretionary fiscal policy which was designed ex-ante to be procyclical, did not in fact react to the cycle (being acyclical) due to the errors made in the real-time output gap forecast. As shown in Fig. 1, the forecasts for the output gap of year $t$ made in the spring of $t-1$

\footnotetext{
17 There are some possible explanations as to why the results of this section differ from the conclusions of Forni and Momigliano (2004): a) the time period is different (1999-2006 versus 1993-2003 in their case); b) this section does not distinguish a reaction to positive output gaps from a reaction to negative ones as the authors did; c) the authors include a dummy for Maastricht restrictions, which is not included in this estimate. To gain more insight into such possibilities, a regression was done using Forni and Momigliano (2004) real-time output gap estimate (in the "expected conditions" case) along with the rest of this paper dataset. For the period 1993-2003, used by the authors, a negative coefficient is found for the gap (signalling a countercyclical policy), yet this coefficient is not statistically significant. Furthermore, when the estimation period is restricted to the euro period (1999-2003), i.e. overlapping most of the time period of the regressions presented in this section, the estimated gap coefficient is very small and positive, and in fact not statistically significant. Hence, it appears that Forni and Momigliano's (2004) results are possibly dependent on the sample of countries used, and on the specific time frame used. As seen earlier, fiscal policy did not behave homogenously in Europe in the post-Maastricht period. As a result, some structural breaks might have occurred in the period used by the authors (1993-2003).
} 

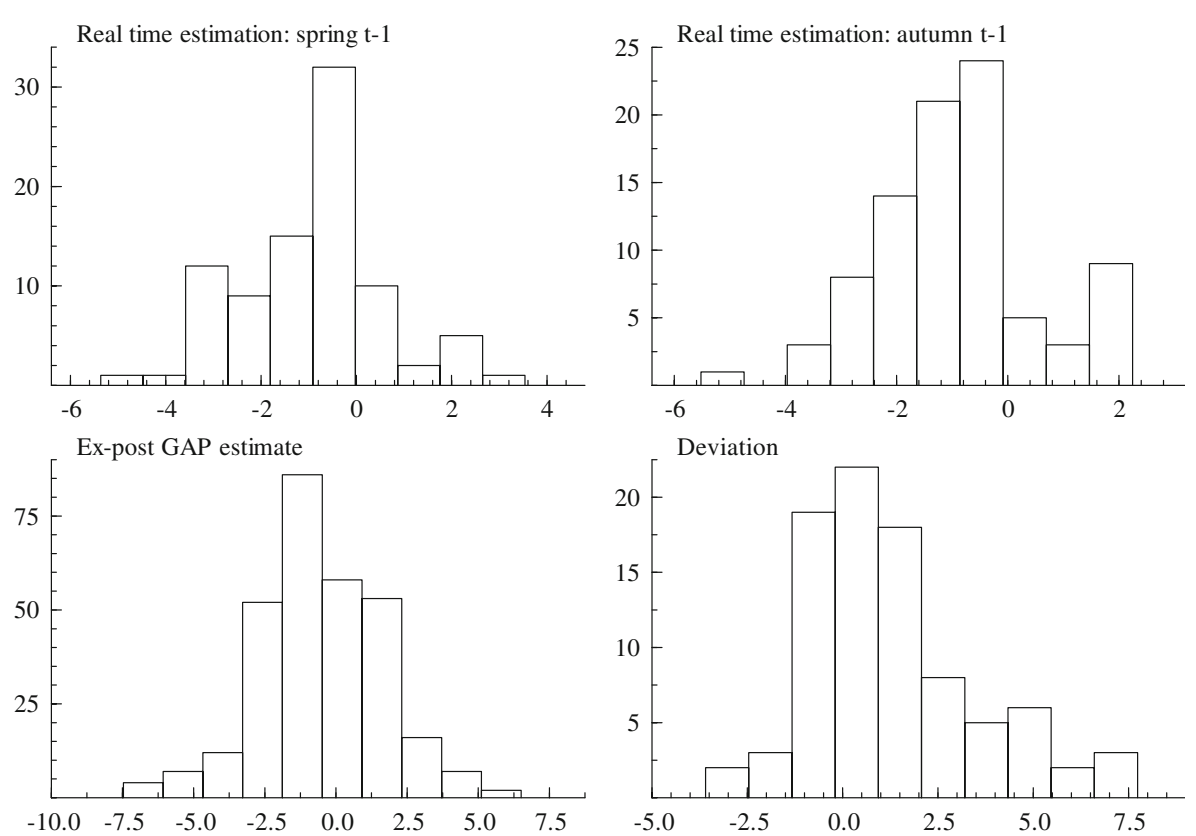

Fig. 1 Output gap forecasts 1999-2006. Notes: The first three graphs represent the distribution of the output gap estimate for euro-area countries (made in $\operatorname{spring}_{t-1}$; autumn $_{t-1}$; ex-post estimate). The last graph represents the distribution of the deviation between the ex-post estimate for year $t$ and the forecast made in $\left.\operatorname{spring}_{t-1}\right)$

since 1999 were less favourable (more negative) than the actual ex-post output gaps, resulting in mainly positive deviations vis-à-vis the spring forecast made in the previous year. This is mainly due to an overestimation of the growth potential of economies in the early $2000 \mathrm{~s}$, probably a hangover from the dot.com bubble which suggested better future prospects. ${ }^{18}$ As a result, the evolution of the economy in the early 2000 s appeared to be less favourable than it was in reality, leading to the estimation of worse (more negative) real-time output gaps than the actual ex-post gaps. ${ }^{19}$

The results obtained with the use of real-time data cast some doubts on the conclusions derived from evidence presented in the previous sections, since the actual acyclical behaviour of discretionary fiscal policy in the 1999-2006 period seems to be simply the result of errors in the real-time forecast of the output gap, and

\footnotetext{
${ }^{18}$ For example, for France the 1999 forecast for the output gap in 2000, in the "Broad Economic Policy Guidelines", was predicted to be $-2.3 \%$. The ex-post data, as available in the spring of 2007 forecast, pointed to a positive output gap of $2.4 \%$, i.e. to a deviation of $4.7 \%$ of the potential GDP. For Germany, the numbers are similar (the initial forecast was $-0.7 \%$ and the ex-post value is $1.3 \%$ ). For Italy, the figures for 2000 are $3.1 \%$ (ex-ante) vs. 1.8\% (ex-post), and for Spain -3.1\% (ex-ante) vs. $2.2 \%$ (ex-post).

${ }^{19}$ According to Jonung and Larch (2006), there is an even greater degree of optimism in the medium-term growth outlook in national official government's growth projections for France, Germany, Italy and the United Kingdom. Such optimism has resulted in cyclical conditions that systematically turn out to be better than assumed at the time of presenting the budget deficit.
} 
not the result of a deliberate change in the intentions of policy-makers to avoid a countercyclical use of discretionary fiscal policy. According to this section's results, there is no evidence to support the view that the Maastricht rules have forced policymakers to change their behaviour to start planning countercyclical discretionary fiscal policies.

\section{Concluding remarks}

Some economists feared that the Maastricht rules would force fiscal policy in the euro area to be procyclical. The study by Galí and Perotti (2003) was among the first influential papers to find some evidence against this view. Using data for the period 1980-2003, Galí and Perotti (2003) found that discretionary budget deficits actually became more countercyclical in EMU countries after the Maastricht Treaty than before. This paper contributes to this literature by testing for the robustness of such conclusions to: i) a different dataset; ii) a different sub-period division; iii) an extension of the estimation period to 2006, i.e. including three more years of the EMU; iv) to control for the effects of political-institutional variables on the cyclically adjusted primary deficit, and v) to the use of real-time data for the period after the introduction of the euro.

Overall, this paper finds that the results of Galí and Perotti (2003) are broadly robust to the first four changes using ex-post data, but not to the use of real-time data. Using a panel data approach for the EU-15 countries, and ex-post data, it is found that discretionary fiscal policy is procyclical before the signing of the Maastricht Treaty in 1992. After 1992, it becomes acyclical. However, there is considerable variation in the after-Maastricht period. Immediately after the signing of the Treaty (1992-1995) discretionary fiscal policy becomes countercyclical. However, in the three years after the decision on the start of stage III of the EMU was taken, in December 1995, i.e. in the run-up to the single currency period (19961998), discretionary fiscal policy becomes strongly procyclical again. Once the euro became a reality in 1999, it appears that discretionary fiscal policy was acyclical in the euro-area countries (and also in the EU-15). Yet, there is some degree of variation at the country level. Distinguishing high-deficit from low-deficit countries, there is some evidence in favour of the view that low-deficit countries tend to pursue more countercyclical discretionary fiscal policies.

Controlling for the influence of political-institutional variables does not change the overall conclusion regarding the cyclical properties of discretionary fiscal policy. The realization of elections is found to have a positive impact on the cyclically adjusted primary deficit (CAPD). The CAPD also increases with the number of spending ministers in the government. Interestingly enough, it was found that coalition governments tend to pursue a more countercyclical discretionary fiscal policy. On the other hand, a large number of spending ministers might lead to procyclical fiscal decisions.

These first four robustness checks were based on the use of instrumental variables to proxy for the expected output gap in the fiscal rule, estimated using ex-post data. However, in practice policy-makers have to resort to real-time estimation of the output gaps when deciding fiscal policy. Hence, it is important to check the 
robustness of previous results to the use of real-time data. A practical difficulty is the length of real-time data: the European Commission forecasts for the output gap only started to be published on a regular basis in 1999. Hence, it is not possible to assess the impact of the SGP using real-time data. Nonetheless, it is possible to estimate the fiscal reaction function since 1999. Using these data, an interesting conclusion emerges: in the euro area, discretionary fiscal policy in the period after the introduction of the euro has been designed (according to the information available at the time) to be procyclical. However, the economic conditions have been, in general, more favourable than initially estimated, leading to forecasting errors in the output gap estimates, making actual discretionary fiscal policy acyclical in the period 19992006 when evaluated using ex-post data. This conclusion contrasts with the results of Forni and Momigliano (2004).

All in all, there is some evidence, using ex-post data, pointing to a more countercyclical use of discretionary fiscal policy (or at least to less use of procyclical discretionary fiscal policy), but there is no definitive evidence (yet) that the SGP rules have made fiscal policy countercyclical over the cycle, at least not for all euroarea countries. However, the use of real-time data for the period 1999-2006 reveals that discretionary fiscal policy was designed to be procyclical. Hence, the actual acyclical behaviour of discretionary fiscal policy in the period after 1999 seems to be simply the result of errors in the forecast of the output gap, and not the result of a change in the intentions of policy-makers. There is, therefore, no evidence in favour of the view that the Maastricht rules have forced euro-area policy-makers to change their behaviour and start planning countercyclical discretionary fiscal policies.

Acknowledgement The text has benefited from comments received from an anonymous referee and from António Afonso, Martin Larch, Peter Brandner, José Tavares, Alfred Sitz and other participants at the $63^{\text {rd }}$ International Atlantic Economic Conference held in Madrid on 14-18 March 2007, and at the Workshop on the Sustainability of the Public Debt held at Klagenfurt University on 20 May 2007. All remaining errors or omissions are solely my responsibility. A word of recognition is also due to Jochen Mierau, Richard Jong-A-Pin and Jakob de Haan for making their data set on political variables available, and to Reinhard Neck for superbly organizing the two mentioned sessions. The author also acknowledges financial support provided by the Portuguese Foundation for Science and Technology (FCT) under research grant POCI/EGE/60069/2004 (partially funded by FEDER, programme POCI 2010). 


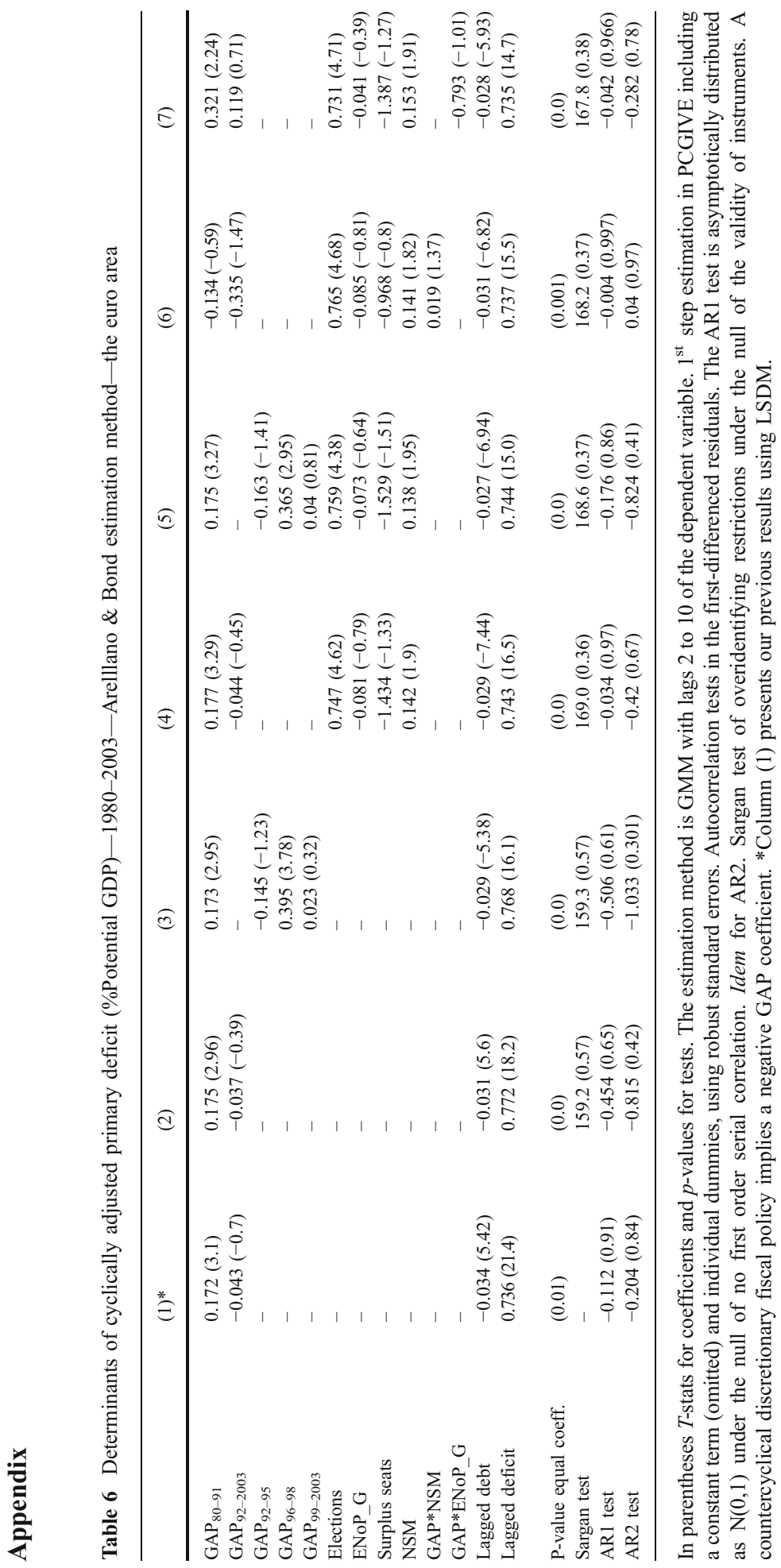


Table 7 Determinants of cyclically adjusted primary deficit (\%Potential GDP) in the euro area - country level results: 1980-2006

\begin{tabular}{|c|c|c|c|c|c|c|c|c|}
\hline & Country & $\mathrm{GAP}_{80-91}$ & $\mathrm{GAP}_{92-95}$ & $\mathrm{GAP}_{96-98}$ & $\mathrm{GAP}_{99-2006}$ & $\begin{array}{l}P \text {-value } \\
\text { BM-AM }\end{array}$ & $\begin{array}{l}P \text { value } \\
\text { BM-A€ }\end{array}$ & $\begin{array}{l}P \text { - } \\
\text { value } \\
\mathrm{J} \text { test }\end{array}$ \\
\hline \multirow{5}{*}{$\begin{array}{l}\text { High- } \\
\text { deficit } \\
\text { countries }\end{array}$} & Belgium & $0.160(0.51)$ & $0.482(1.66)$ & $0.491(0.92)$ & $-0.112(-0.27)$ & 0.764 & 0.502 & 0.319 \\
\hline & Greece & $0.969(4.46)$ & $0.944(2.59)$ & $1.564(6.25)$ & $1.592(2.99)$ & 0.146 & 0.283 & 0.328 \\
\hline & Ireland & $0.327(2.36)$ & $-0.008(-0.06)$ & $0.292(5.56)$ & $0.234(1.11)$ & 0.098 & 0.711 & 0.194 \\
\hline & Italy & $0.782(4.24)$ & $0.648(2.15)$ & $1.662(1.92)$ & $-0.06(-0.22)$ & 0.099 & 0.016 & 0.089 \\
\hline & Portugal & $0.175(1.54)$ & $-0.128(-0.5)$ & $0.131(0.19)$ & $0.103(0.411)$ & 0.732 & 0.805 & 0.04 \\
\hline \multirow{6}{*}{$\begin{array}{l}\text { Low- } \\
\text { deficit } \\
\text { countries }\end{array}$} & Austria & $0.342(2.0)$ & $-1.135(-3.82)$ & $1.16(2.11)$ & $0.027(0.15)$ & 0.0 & 0.151 & 0.123 \\
\hline & Finland & $-0.121(-1.07)$ & $-0.469(-5.53)$ & $-0.221(-2.0)$ & $-0.591(-1.53)$ & 0.069 & 0.247 & 0.773 \\
\hline & Germany & $0.528(7.61)$ & $0.069(0.52)$ & $0.431(0.89)$ & $-0.269(-0.39)$ & 0.0 & 0.262 & 0.293 \\
\hline & France & $0.301(2.34)$ & $-0.071(-0.21)$ & $0.678(5.76)$ & $0.05(0.347)$ & 0.0 & 0.204 & 0.565 \\
\hline & Netherlands & $0.233(1.37)$ & $0.375(0.78)$ & $0.693(0.84)$ & $-0.065(-0.31)$ & 0.589 & 0.237 & 0.316 \\
\hline & Spain & $0.160(1.58)$ & $-0.302(-1.88)$ & $-0.042(-0.18)$ & $0.576(2.22)$ & 0.06 & 0.08 & 0.297 \\
\hline
\end{tabular}

Results for lagged deficit and debt omitted. T-values based on robust standard errors. High deficit countries: countries that presented an average cyclically adjusted deficit in the period 1980-1995 larger than the unweighted euro-area average

\section{References}

Andersen T (2001) Stabilization policy, University of Aarhus, unpublished manuscript, June

Arellano M, Bond S (1991) Some tests of specification for panel data: Monte Carlo evidence and an application to employment equations. Rev Econ Stud 58:227-297

Auerbach A (2002) Is there a role for discretionary fiscal policy?, NBER Working Paper No. 9306

Baltagi B (2001) Econometric analysis of panel data. 2nd edition, Wiley \& Sons Chichester

Bayoumi T, Masson P (1995) Fiscal flows in the United States and Canada: lessons for monetary union in Europe. Eur Econ Rev 39:253-274

Brandner P, Diebalek L and Koehler-Toeglhofer (2006) Budget balances decomposed: tracking fiscal policy in Austria. Presented at the Workshop on Fiscal Indicators in the EU Budgetary Surveillance, Brussels, 22 September

Brender A, Drazen A (2005) Political budget cycles in new versus established democracies. J Mon Econ 52:1271-1295

Forni L, Momigliano S (2004) Cyclical sensitivity of fiscal policies based on real-time data. App Econ Q 50:299-326

Galí J, Perotti R (2003) Fiscal policy and monetary integration in Europe. Econ Policy 37:533-572

Jonung L, Larch M (2006) Improving fiscal policy in the EU: the case for independent forecasts. Econ Policy 21:491-534

Lane P (2003) The cyclical behaviour of fiscal policy: Evidence from the OECD. J Pub Econ 87:26612675

Mierau Jo, Jong-a-Pin R and De Haan J (2006) Do political variables affect fiscal policy adjustment decisions? New empirical evidence, Paper submitted for EPCS2006

Mierau J, Jong-a-Pin R and De Haan J (2007) Do political variables affect fiscal policy adjustment decisions? New empirical evidence. Pub Choice 133(3-4):297-319

Orphanides A, Van Norden S (2002) The unreliability of output-gap estimates in real time. Rev Econ Stat $84: 569-583$

Pina Á (2004) Fiscal policy in Portugal: discipline, cyclicality and the scope for expenditure rules, proceedings of the 2nd Conference on Portuguese Economic Development in the European Context, held by the Bank of Portugal in Lisbon, 11-12 March 2004, forthcoming

Roubini N, Sachs J (1989) Political and economic determinants of budget deficits in the industrial democracies. Eur Econ Rev 33:903-933 
Volkerink B, De Haan J (2001) Fragmented government effects on fiscal policy: new evidence. Pub Choice 109:221-242

Woo J (2003) Economic, political, and institutional determinants of public deficits. J Pub Econ 87:387426

Wyplosz C (2002) Fiscal Discipline in EMU: rules or institutions? Paper prepared for the April 16, 2002 meeting of the Group of Economic Analysis of the European Commission. http://heiwww.unige.ch/ $\sim$ wyplosz/ 